\title{
IL-1 receptor antagonist restores IL-18 NK cell axis in systemic JIA
}

\author{
Sebastiaan J Vastert, Wilco De Jager, Bo Jan Noordman, Berent J Prakken, Nico M Wulffraat \\ From 7th European Workshop on Immune-Mediated Inflammatory Diseases \\ Noordwijk aan Zee, the Netherlands. 28-30 November 2012
}

\section{Background}

Systemic onset juvenile idiopathic arthritis (SoJIA) is an acquired auto-inflammatory disease characterized by systemic inflammation and innate immune activation reflected by uncontrolled production of cytokines such as IL-1, IL- 6 and IL-18. In SoJIA, NK cell function is severely hampered despite high levels of IL-18.

We recently found that defective phosphorylation of the IL-18 receptor beta is responsible for the deficient IL-18-NK cell axis in SoJIA.

\section{Aim}

To study first line treatment with recombinant IL-1 receptor antagonist (rIL-1RA, Anakinra) in 16 newly diagnosed and steroid naïve systemic onset JIA patients.

\section{Materials and methods}

Clinical outcome was measured using ACRp70 and ACRp90. Furthermore, NK cell lytic function, inflammasome activity and cytokine levels in plasma were assessed during follow up (max 3 years).

\section{Results}

Here we show that patients with SoJIA have increased inflammasome activation leading to elevated IL-18 levels. First line treatment in steroid naïve patients, with rIL-1RA effectively down-regulated IL-18 levels through suppression of inflammasome activation and led to rapid resolution of clinical features in 87\% (ACRp90) of patients. Furthermore, using rIL-1RA as first line treatment approach the defective IL-18-NK cell axis is restored as shown by improved lytic NK cell function and regaining of the NK cell responsiveness to IL-18 stimulation.

Dept. of Pediatric Immunology, University Medical Center Utrecht, Utrecht, the Netherlands

\section{Conclusions}

These data suggest that the mechanisms of inflammatory control induced by rIL-1RA in SoJIA patients involves more than blocking IL-1R. Our data show that rIL-1RA directly targets the inflammasome and restores the IL-18 NK cell axis as well.

Published: 28 November 2012

doi:10.1186/1479-5876-10-S3-P45

Cite this article as: Vastert et al:: IL-1 receptor antagonist restores IL-18 NK cell axis in systemic JIA. Journal of Translational Medicine 2012 10(Suppl 3):P45.
Submit your next manuscript to BioMed Central and take full advantage of:

- Convenient online submission

- Thorough peer review

- No space constraints or color figure charges

- Immediate publication on acceptance

- Inclusion in PubMed, CAS, Scopus and Google Scholar

- Research which is freely available for redistribution
C Biomed Central
C Biomed Central

@ 2012 Vastert et al; licensee BioMed Central Ltd. This is an Open Access article distributed under the terms of the Creative Commons Attribution License (http://creativecommons.org/licenses/by/2.0), which permits unrestricted use, distribution, and reproduction in any medium, provided the original work is properly cited. 